\title{
The impact of nitrogen deposition on acid grasslands in the Atlantic region of Europe
}

\author{
Carly J. Stevens ${ }^{\mathrm{a}, \mathrm{b}}$, Cecilia Duprè ${ }^{\mathrm{c}}$, Edu Dorland ${ }^{\mathrm{d}}$, \\ Cassandre Gaudnik ${ }^{e}$, David J.G. Gowing ${ }^{a}$, Albert Bleeker ${ }^{f}$, \\ Martin Diekmann ${ }^{\mathrm{c}}$, Didier Alard ${ }^{\mathrm{e}}$, Roland Bobbink ${ }^{\mathrm{g}}$, David Fowler ${ }^{\mathrm{h}}$, \\ Emmanuel Corcket ${ }^{\mathrm{e}}$, J. Owen Mountford', Vigdis Vandvik ${ }^{\mathrm{j}}$, \\ Per Arild Aarrestad ${ }^{k}$, Serge Muller', Nancy B. Dise ${ }^{m}$
}

a Department of Life Sciences, The Open University, Walton Hall, Milton Keynes MK7 6AA, UK b Lancaster Environment Centre, Lancaster University, Lancaster LA1 4YQ, UK

c Institute of Ecology, FB 2, University of Bremen, Leobener Str., DE-28359 Bremen, Germany

d Ecology \& Biodiversity Group, Department of Biology, Institute of Environmental Biology, Utrecht University, PO Box 80.058, 3508 TB Utrecht, The Netherlands

e University of Bordeaux 1, UMR INRA 1202 Biodiversity, Genes and Communities, Equipe Ecologie des Communautés, Bâtiment B8 e Avenue des Facultés, F-33405 Talence, France

f Department of Air Quality \& Climate Change, Energy Research Centre of the Netherlands, PO Box 1, 1755 ZG Petten, The Netherlands

g B-WARE Research Centre, Radboud University, PO Box 9010, 6525 ED Nijmegen, The Netherlands

h NERC Centre for Ecology and Hydrology, Bush Estate, Penicuik, Midlothian EH26 0QB, UK i NERC Centre for Ecology \& Hydrology, MacLean Building, Benson Lane, Crowmarsh Gifford, Wallingford, Oxfordshire OX10 8BB, UK

j Department of Biology, University of Bergen, Box 7800, N-5020 Bergen, Norway

k Norwegian Institute for Nature Research, PO Box 5685, Sluppen, NO-7485 Trondheim, Norway I Laboratoire des Interactions Ecotoxicologie, Biodiversité et Ecosystèmes (LIEBE), UMR CNRS 7146, U.F.R. Sci. F.A., Campus Bridoux, Université Paul Verlaine, Avenue du Général Delestraint F 57070 Metz, France

mDepartment of Environmental and Geographical Science, Manchester Metropolitan University, Manchester M1 5GD, UK 
Provided for non-commercial research and education use. Not for reproduction, distribution or commercial use.

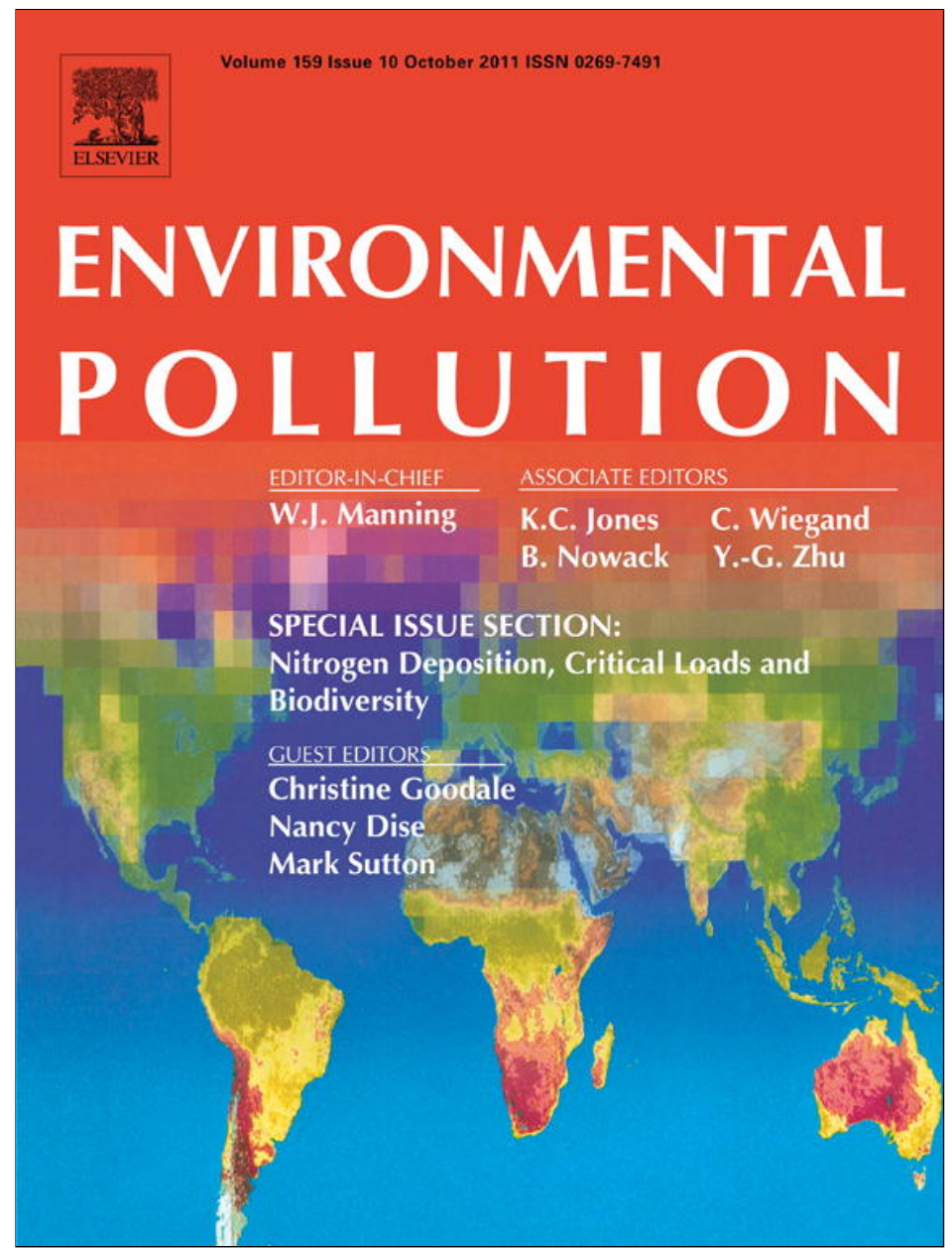

This article appeared in a journal published by Elsevier. The attached copy is furnished to the author for internal non-commercial research and education use, including for instruction at the authors institution and sharing with colleagues.

Other uses, including reproduction and distribution, or selling or licensing copies, or posting to personal, institutional or third party websites are prohibited.

In most cases authors are permitted to post their version of the article (e.g. in Word or Tex form) to their personal website or institutional repository. Authors requiring further information regarding Elsevier's archiving and manuscript policies are encouraged to visit:

http://www.elsevier.com/copyright 


\title{
The impact of nitrogen deposition on acid grasslands in the Atlantic region of Europe
}

\author{
Carly J. Stevens ${ }^{\mathrm{a}, \mathrm{b}, *}$, Cecilia Duprè ${ }^{\mathrm{c}}$, Edu Dorland ${ }^{\mathrm{d}, 1}$, Cassandre Gaudnik ${ }^{\mathrm{e}}$, David J.G. Gowing ${ }^{\mathrm{a}}$, \\ Albert Bleeker ${ }^{\mathrm{f}}$, Martin Diekmann ${ }^{\mathrm{c}}$, Didier Alard ${ }^{\mathrm{e}}$, Roland Bobbink ${ }^{\mathrm{g}}$, David Fowler ${ }^{\mathrm{h}}$, \\ Emmanuel Corcket ${ }^{\mathrm{e}}$, J. Owen Mountford ${ }^{\mathrm{i}}$, Vigdis Vandvik $^{\mathrm{j}}$, Per Arild Aarrestad ${ }^{\mathrm{k}}$, \\ Serge Muller ${ }^{1}$, Nancy B. Dise ${ }^{\mathrm{m}}$ \\ a Department of Life Sciences, The Open University, Walton Hall, Milton Keynes MK7 6AA, UK \\ ${ }^{\mathrm{b}}$ Lancaster Environment Centre, Lancaster University, Lancaster LA1 4YQ UK \\ ${ }^{\mathrm{c}}$ Institute of Ecology, FB 2, University of Bremen, Leobener Str., DE-28359 Bremen, Germany \\ ${ }^{\mathrm{d}}$ Ecology E Biodiversity Group, Department of Biology, Institute of Environmental Biology, Utrecht University, PO Box 80.058, 3508 TB Utrecht, The Netherlands \\ e University of Bordeaux 1, UMR INRA 1202 Biodiversity, Genes and Communities, Equipe Ecologie des Communautés, Bâtiment B8 - Avenue des Facultés, F-33405 Talence, France \\ ${ }^{\mathrm{f}}$ Department of Air Quality \& Climate Change, Energy Research Centre of the Netherlands, PO Box 1, 1755 ZG Petten, The Netherlands \\ ${ }^{g}$ B-WARE Research Centre, Radboud University, PO Box 9010, 6525 ED Nijmegen, The Netherlands \\ ${ }^{\mathrm{h}}$ NERC Centre for Ecology and Hydrology, Bush Estate, Penicuik, Midlothian EH26 OQB, UK \\ ${ }^{\mathrm{i}}$ NERC Centre for Ecology E Hydrology, MacLean Building, Benson Lane, Crowmarsh Gifford, Wallingford, Oxfordshire OX10 8BB, UK \\ ${ }^{\mathrm{j}}$ Department of Biology, University of Bergen, Box 7800, N-5020 Bergen, Norway \\ ${ }^{\mathrm{k}}$ Norwegian Institute for Nature Research, PO Box 5685, Sluppen, NO-7485 Trondheim, Norway \\ ${ }^{1}$ Laboratoire des Interactions Ecotoxicologie, Biodiversité et Ecosystèmes (LIEBE), UMR CNRS 7146, U.F.R. Sci. F.A., Campus Bridoux, Université Paul Verlaine, Avenue du Général \\ Delestraint F 57070 Metz, France \\ ${ }^{\mathrm{m}}$ Department of Environmental and Geographical Science, Manchester Metropolitan University, Manchester M1 5GD, UK
}

\section{A R T I C L E I N F O}

Article history:

Received 1 July 2010

Received in revised form

16 November 2010

Accepted 22 November 2010

\section{Keywords:}

Atmospheric nitrogen deposition

Plant functional group

Plant-tissue nitrogen

Soil C:N

Soil pH

\begin{abstract}
A B S T R A C T
A survey of 153 acid grasslands from the Atlantic biogeographic region of Europe indicates that chronic nitrogen deposition is changing plant species composition and soil and plant-tissue chemistry. Across the deposition gradient $\left(2-44 \mathrm{~kg} \mathrm{~N} \mathrm{ha}^{-1} \mathrm{yr}^{-1}\right)$ grass richness as a proportion of total species richness increased whereas forb richness decreased. Soil C:N ratio increased, but soil extractable nitrate and ammonium concentrations did not show any relationship with nitrogen deposition. The above-ground tissue nitrogen contents of three plant species were examined: Agrostis capillaris (grass), Galium saxatile (forb) and Rhytidiadelphus squarrosus (bryophyte). The tissue nitrogen content of neither vascular plant species showed any relationship with nitrogen deposition, but there was a weak positive relationship between $R$. squarrosus nitrogen content and nitrogen deposition. None of the species showed strong relationships between above-ground tissue N:P or C:N and nitrogen deposition, indicating that they are not good indicators of deposition rate.
\end{abstract}

(c) 2010 Elsevier Ltd. All rights reserved.

\section{Introduction}

Atmospheric nitrogen $(\mathrm{N})$ deposition is a global environmental problem. Nitrogen oxides are predominantly emitted from the burning of fossil fuels. Between 1980 and 2003 most of Europe (excluding Portugal, Spain and Greece) saw a reduction in oxidised

\footnotetext{
* Corresponding author.

E-mail address: c.j.stevens@open.ac.uk (C.J. Stevens).

1 Present address: KWR Watercycle Research Institute, P.O.Box 1072, 3430 BB Nieuwegein, The Netherlands.
}

$\mathrm{N}$ emissions of between 20 and 50\%. This downward trend is generally reflected in wet deposition (in rainfall) but not in dry deposition (as a gas or fine particulate) (Fagerli and Aas, 2008). For ammonia emissions and deposition the pattern is much more mixed, with some European countries showing small decreases and others increase. $90 \%$ of ammonia emissions are from agricultural sources (Erisman et al., 2008) and consequently can vary greatly within a small area. Nevertheless, total deposition of $\mathrm{N}$ remains high in many parts of Europe and critical loads (thresholds above which there is risk of damage to sensitive components of the ecosystem) are already exceeded in many countries (Galloway et al., 2008), representing a threat to biodiversity and ecosystem services 
(Mace et al., 2005). Indeed, $\mathrm{N}$ deposition is forecast to be, together with land use and climate change, in the top three drivers of change in global biodiversity by the year 2100 (Sala et al., 2000).

Nitrogen deposition has a number of different potential impacts on semi-natural ecosystems. At high air concentrations $\mathrm{NH}_{3}$ and $\mathrm{NH}_{4}^{+}$are phytotoxic, causing leaf damage and growth reduction (e.g. Pearson and Stewart, 1993; Sheppard and Leith, 2002). Concentrations of ammonia high enough to cause direct toxicity are quite rare in Europe and generally only occur in the immediate vicinity of point sources. However, at lower levels, the effects of $\mathrm{N}$ deposition on vegetation can still be observed, including soil-mediated effects of eutrophication and acidification, and increased susceptibility to secondary stress (Bobbink et al., 2010).

In many semi-natural terrestrial ecosystems $\mathrm{N}$ is the limiting nutrient, so the addition of $\mathrm{N}$ has the potential to increase primary productivity. This can lead to increased plant competition for other resources, such as light and phosphorus, shifting the plant community towards one dominated by more competitive species (e.g. Bobbink et al., 1998; Clark et al., 2007; Hautier et al., 2009). Grasses are generally considered to be the more productive component of grasslands and are frequently thought to increase in response to eutrophication, shading out stress-tolerant components of the sward (e.g. Hautier et al., 2009). This results in changes in species composition and the balance of functional groups. The increase in plant litter from the enhanced productivity of vegetation can increase $\mathrm{N}$ turnover. More decomposable species are often favoured and tissue quality increases leading to an increase in $\mathrm{N}$ mineralisation rates (Aerts and Chapin, 2000). Other effects of $\mathrm{N}$ deposition include an increased susceptibility to insect herbivory, such as the increased frequency and intensity of attacks on Calluna vulgaris from the heather beetle (Lochmaea suturalis) (e.g. Brunsting and Heil, 1985). Increased attacks from insect herbivores are thought to be related to elevated concentrations of $\mathrm{N}$ in plant tissues and decreased concentrations of carbon (C) -based defensive compounds (Throop and Lerdau, 2004). Indeed, many studies have reported changes in plant-tissue chemistry related to $\mathrm{N}$ deposition (e.g. Pitcairn et al., 1998; Gidman et al., 2006). N deposition also leads to an increased incidence of drought and frost stress (e.g. Carroll et al., 1999), which, due to species differences in susceptibility, can alter plant species composition.

Deposition of acids in precipitation, oxidation of dry-deposited compounds, loss of basic cations through ion exchange, plant uptake, and nitrification of ammonium, result in a reduction of soil $\mathrm{pH}$ either directly or indirectly related to $\mathrm{N}$ deposition (Bobbink et al., 2010). Increased soil acidity can have a number of potential consequences including increased solubility of potentially toxic metals, changes to nutrient cycling, reducing or changing the populations of soil microbes and fauna, and changing plant species composition and richness (Johnston et al., 1986; FalkengrenGrerup, 1995; Stevens et al., 2004, 2009a). The potential for $\mathrm{N}$ deposition to impact plant species composition, soil chemistry and plant-tissue chemistry has been clearly demonstrated in numerous $\mathrm{N}$ addition experiments in a range of habitats (e.g. Phoenix et al., 2003; Pilkington et al., 2005; Berger et al., 2009). However, there have been far fewer investigations on whether these changes are actually occurring at a regional scale. There have been several studies in Great Britain demonstrating changes in plant species richness and composition (e.g. Stevens et al., 2004; Maskell et al., 2010) and soil chemistry (e.g. Stevens et al., 2006; Stevens et al., 2009a) across an $\mathrm{N}$ deposition gradient but, until now, none that investigate correlations between $\mathrm{N}$ deposition and soil chemistry and plant-tissue chemistry in acid grasslands at a European scale.

Here we report data from a study that gathered data on species composition, soil chemistry and plant-tissue chemistry from 153 acid grasslands in 13 different countries within the Atlantic biogeographic zone of Europe. This was used to test the hypotheses that 1) the proportion of species richness accounted for by forbs will decrease whilst the proportion of species richness accounted for by grasses will increase; 2) Al:Ca ratio and soil nitrogen (available nitrate, ammonium and total $\mathrm{N}$ ) will increase and $\mathrm{C}: \mathrm{N}$ ratio will decrease with increasing $\mathrm{N}$ deposition and 3) the nitrogen concentration of plant tissues will increase with increasing $\mathrm{N}$ deposition. Richness of functional groups as a proportion of total species richness was used to assess relative changes in composition and to determine whether the proportion of richness made up by the functional groups is changing rather than changes observed being a function of changing richness. The results of this study will demonstrate impacts of ambient levels of $\mathrm{N}$ deposition over a largescale spatial gradient providing evidence for European policy and, in particular, the development of critical loads for nitrogen.

\section{Methods}

153 acid grasslands belonging to the Violion caninae association (Schwickerath 1944) were surveyed within the Atlantic biogeographic zone of Europe (Fig. 1). This community is typically dominated by grasses including Agrostis capillaris and Festuca ovina or rubra with forbs such as Galium saxatile and Potentilla erecta and bryophytes including Rhytidiadelphus squarrosus occurring at a high constancy. Soils are variable in texture and of acidic $\mathrm{pH}$ (approximately $\mathrm{pH}$ 3.5-6). This community is found throughout the Atlantic biogeographic region of Europe. The grasslands were selected to cover the range of atmospheric $\mathrm{N}$ deposition in Europe ( $\mathrm{N}$ deposition at sites ranged from 2 to $44 \mathrm{~kg} \mathrm{~N} \mathrm{ha}^{-1} \mathrm{yr}^{-1}$ ). None of the grasslands surveyed were fertilised and all were managed by grazing or cutting. Areas within the grassland that belonged to other plant communities or were strongly affected by animals, tracks and paths, or were in the rain shadows of trees or hedges were excluded from the survey. Surveys were conducted between May and September in 2002/3 and 2007. At each site, five randomly located $2 \times 2 \mathrm{~m}$ quadrats were surveyed within a 1 ha area. Within each quadrat all vascular plants and bryophytes were identified to a species level. A description of the site was made including latitude, longitude, aspect, slope, patch size of the habitat from which the sample was taken, soil depth, management intensity (estimated based on vegetation height and number of grazing animals on a scale of one to three from intensive to extensive) and dominant species in adjacent vegetation communities.

Soil samples were collected from each quadrat. Topsoil samples were taken at a depth of 0-10 cm below the litter layer. Samples were taken from two opposing corners of the quadrat using a trowel and bulked to give one sample per quadrat. Subsoil samples were taken at a depth of $20-30 \mathrm{~cm}$ deep or, where soils were shallower than $20 \mathrm{~cm}$, as deep as possible. Subsoil samples were taken from the

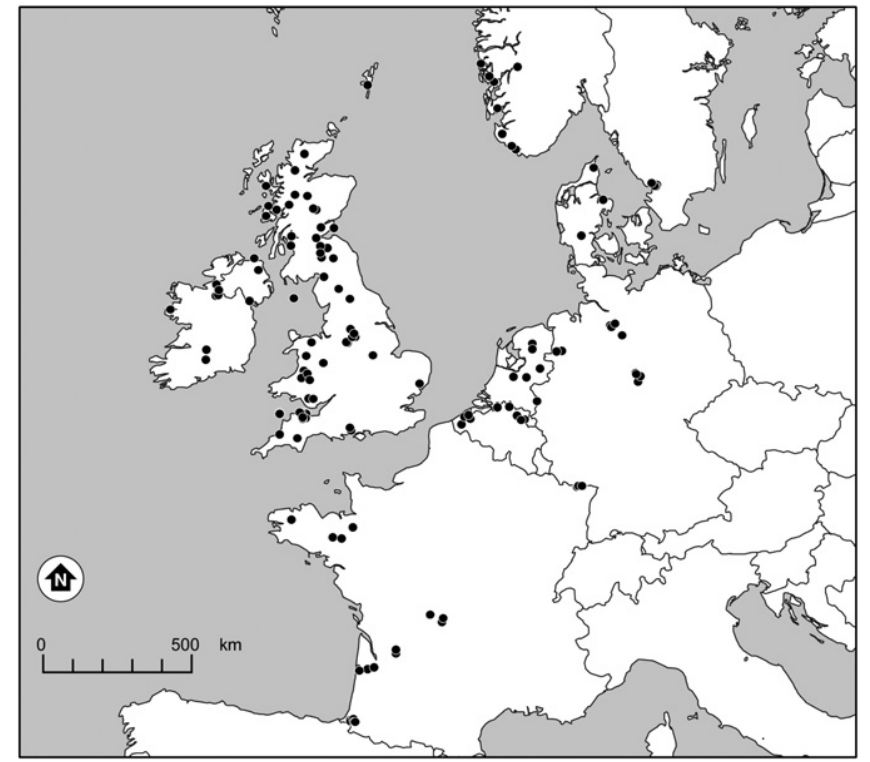

Fig. 1. Map of the 153 acid grasslands surveyed in the Atlantic biogeographic zone of Europe. 
centre of the quadrat using a $5 \mathrm{~cm}$ diameter soil auger. All soil samples were bagged and kept cool during transit.

Plant-tissue samples were collected from within the vicinity of the quadrats. Approximately two grams (dry weight) of above-ground material were collected for three species: Agrostis capillaris L. (bent grass), Galium saxatile L. (lady's bedstraw) and the moss Rhytidiadelphus squarrosus (Hedw.) Warnst at all sites where the species occurred. These species were selected as they are both common and abundant throughout the geographical area investigated in this project. Only living material was collected. Samples were washed in deionised water.

In the laboratory, soil samples were air dried, roots and stones removed and remaining soil ground to $<2 \mathrm{~mm}$ prior to analysis using a pestle and mortar. For total carbon $(\mathrm{C}$ ) and $\mathrm{N}$ analysis, soils were ground to a fine powder. Plant samples were oven dried for three days at $55{ }^{\circ} \mathrm{C}$ and then ground to $<2 \mathrm{~mm}$.

Nitrate, ammonium, dissolved calcium ( $\mathrm{Ca})$ and aluminium $(\mathrm{Al})$ concentrations were analysed using two different methods. Samples collected in 2002 and 2003 were leached with $1 \mathrm{M} \mathrm{KCl}$ and the resulting nitrate and ammonium analysed using an ion chromatograph. Other samples were shaken with $0.4 \mathrm{M} \mathrm{NaCl}$ and analysed using an auto-analyser. For all samples metal concentrations were determined using an ICP-MS. A comparison between the two methodologies was made to ensure they were compatible. Total $\mathrm{C}$ and $\mathrm{N}$ content of the soil and plant material was analysed using a CN element analyser. Plant-tissue phosphorus (P) concentration was determined using a dry ashing extraction method (Chapman and Pratt, 1985; Ryan et al., 2001) followed by a Barton colour complex (MAFF, 1986). Absorbance was determined using a colorimeter at a wavelength of $410 \mathrm{~nm}$. Soil pH was determined using a $\mathrm{pH}$ probe in a 1:5 slurry of soil and deionised water.

Meteorological data for all the sites were obtained from the European Space Agency Monitoring Agriculture with Remote Sensing (MARS) unit (MARS, 2009). Ten year averages (1996-2006) were calculated for each site for mean annual potential transpiration, mean minimum daily temperature, mean maximum daily temperature and mean annual rainfall. Radiation index (based on latitude, aspect and slope) was calculated according to Oke (1987). The European gradient gives a greater range of $\mathrm{N}$ deposition compared to the UK alone but also covers a broader range of climatic conditions including sites that were wetter, drier, warmer and cooler than found in the UK alone.

For each site, total $\mathrm{N}$, reduced $\mathrm{N}$, oxidised $\mathrm{N}$ and sulphur (S) deposition data were modelled using the best available deposition model. National models were used for Germany (Gauger et al., 2002), the Netherlands (Van Jaarsveld, 2004; Asman and van Jaarsveld, 2002; Van Jaarsveld, 1995) and the United Kingdom (NEGTAP, 2001; Smith et al., 2000). For all other countries the EMEP-based IDEM model (Pieterse et al., 2007) was used. For all of the models, deposition was calculated as a threeyear average (2000-2003) to provide a robust estimate of longer-term $\mathrm{N}$ inputs. Acid deposition was calculated from the molar equivalents of reactive $\mathrm{N}$ and $\mathrm{S}$ $\left(\mathrm{NO}_{3}^{-}+\mathrm{NH}_{4}^{+}+\mathrm{SO}_{4}^{2-}, \mathrm{mmol}_{\mathrm{c}} \mathrm{m}^{-2} \mathrm{y}^{-1}\right)$.

Linear regression and linear mixed-effects models were conducted using $\mathrm{R}$ ( $\mathrm{R}$ Core Development Team, 2007; package nlme). All variables were checked for normality and corrected if necessary and strongly inter-correlated independent variables $(r>0.6)$ were removed from the models. Linear mixed-effects models (dependent variables topsoil $\mathrm{pH}, \mathrm{Al}$, nitrate and ammonium concentrations, total soil C, total soil N, soil C:N and plant-tissue N concentration for Agrostis capillaris, Galium saxatile and Rhytidiadelphus squarrosus) used the following predictors: latitude, longitude, altitude, aspect, inclination, mean maximum daily temperature, mean minimum daily temperature, mean annual rainfall, radiation index, vegetation height, management intensity, total $\mathrm{N}$ deposition and $\mathrm{S}$ deposition, and country as a random variable. For plant-tissue variables soil topsoil $\mathrm{pH}, \mathrm{Al}$, nitrate and ammonium concentrations, total $\mathrm{C}$, total $\mathrm{N}, \mathrm{C}: \mathrm{N}$ were included as predictors. Minimum adequate models were selected manually by deleting variables until only significant variables remained. For plant composition data, the five replicate quadrats at each site were added together to give a list of species per site. Within functional group richness for grasses, forbs and bryophytes was calculated as a proportion of total species richness. Species richness for each functional group is presented in Stevens et al. (2010a).

\section{Results}

\subsection{Nitrogen deposition}

Total inorganic $\mathrm{N}$ deposition ranged from 2 to $44 \mathrm{~kg} \mathrm{~N} \mathrm{ha}^{-1} \mathrm{yr}^{-1}$. Oxidised $\mathrm{N}$ deposition ranged from 1.2 to $18.3 \mathrm{~kg} \mathrm{~N} \mathrm{ha}^{-1} \mathrm{yr}^{-1}$ and reduced deposition ranged from 1.2 to 28.7. Oxidised and reduced deposition was highly correlated with total $\mathrm{N}$ deposition (oxidised: $r=0.85$; reduced: $r=0.96)$ and each other $(r=0.69)$.

\subsection{Functional group composition}

Results for total species richness are presented in Stevens et al. (2010). Species richness of grasses (mean of five $2 \times 2$ m quadrats) ranged from 2.2 to 8.4 species. Grass richness as a proportion of total species richness shows a significant positive relationship with $\mathrm{N}$ deposition $\left(r^{2}=0.21, p<0.001\right)$ (Fig. 2a). Breaking this down into reduced and oxidised $\mathrm{N}$ shows that both have very similar relationships with grass richness (reduced $\mathrm{N}: r^{2}=0.18, p<0.001$, oxidised $\mathrm{N}: r^{2}=0.16, p<0.001$ ). Species richness of forbs (mean of five $2 \times 2$ m quadrats) ranged from 0.2 to 14.4 species. Forb richness as a proportion of total species richness shows a significant negative relationship with $\mathrm{N}$ deposition $\left(r^{2}=0.13, p<0.001\right)$ (Fig. $2 \mathrm{~b}$ ). As with grass richness, both reduced and oxidised $\mathrm{N}$ have very similar negative relationships with forb richness (reduced $\mathrm{N}: r^{2}=0.12, p<0.001$, oxidised $\mathrm{N}: r^{2}=0.10, p<0.001$ ). Species richness of bryophytes (mean of five $2 \times 2$ m quadrats) ranged from 0 to 8 species. Bryophyte richness as a proportion of total species richness shows a weak but significant positive relationship with $\mathrm{N}$ deposition $\left(r^{2}=0.06, p<0.001\right)$ (Fig. 2c). Reduced and oxidised $\mathrm{N}$ also shows similar positive results when analysed against the proportion of bryophytes (reduced $\mathrm{N}: r^{2}=0.06, p<0.01$, oxidised $\left.\mathrm{N}: r^{2}=0.02, p<0.05\right)$.

\subsection{Soil chemistry}

Both topsoil and subsoil pH show a significant negative relationship with total inorganic $\mathrm{N}$ deposition (topsoil: $r^{2}=0.20$, $p<0.001$, subsoil $\mathrm{N} r^{2}=0.20, p<0.001$ ). Both topsoil and subsoil $\mathrm{pH}$ show stronger negative relationships with oxidised $\mathrm{N}$ deposition than reduced $\mathrm{N}$ deposition (Topsoil: reduced $\mathrm{N} r^{2}=0.14$, $p<0.001$, oxidised $\mathrm{N} r^{2}=0.25, p<0.001$; subsoil:reduced $\mathrm{N}$ $r^{2}=0.13, p<0.001$, oxidised $\left.\mathrm{N} r^{2}=0.24, p<0.001\right)$. However, the close correlation between oxidised and reduced deposition mean that this should be interpreted with care. When total acid deposition is used instead of total inorganic $\mathrm{N}$ deposition, the relationship is slightly improved (topsoil $r^{2}=0.25, p<0.001$, subsoil $r^{2}=0.22$, $p<0.001$ ). The minimum adequate linear mixed-effects model for topsoil $\mathrm{pH}$ showed significant effects of $\mathrm{N}$ deposition (parameter value $-0.149, p<0.01$ ), latitude (parameter value $0.412, p<0.001$ ) and inclination (parameter value $-0.006, p<0.01$ ).

Aluminium concentration (In transformed for normality) in the topsoil is negatively correlated with topsoil $\mathrm{pH}\left(r^{2}=0.35\right.$, $p<0.001$ ). There is a weak but significant positive relationship between aluminium concentration and $\mathrm{N}$ deposition $\left(r^{2}=0.07\right.$, $p<0.001$ ). The positive relationship between Al concentration and acid deposition is slightly stronger than with $\mathrm{N}$ deposition $\left(r^{2}=0.11, p<0.001\right)$. The minimum adequate linear mixed-effects model showed significant effects of $\mathrm{N}$ deposition (parameter value $0.01, p<0.05$ ), altitude (parameter value $0.14, p<0.001$ ) and rainfall (parameter value $0.0003, p<0.05$ ). Aluminium: calcium ratio (Al:Ca) (ln transformed for normality) shows a weak but significant positive relationship with $\mathrm{N}$ deposition $\left(r^{2}=0.05\right.$, $p<0.01$ ). There is no improvement in the relationship by using acid deposition rather than $\mathrm{N}$ deposition (data not shown).

Topsoil nitrate concentration (ln transformed for normality) shows no significant relationship with $\mathrm{N}$ deposition $(p=0.92)$. The minimum adequate linear mixed-effects model showed a significant relationship with latitude (parameter value $0.339, p<0.001$ ), altitude (parameter value 0.447, $p<0.05$ ), inclination (parameter value $-0.046, p<0.01$ ) and rainfall (parameter value -0.001 , $p<0.05$ ).

Topsoil ammonium concentration (ln transformed for normality) shows a weak but significant positive relationship with $\mathrm{N}$ deposition $\left(r^{2}=0.03, p<0.05\right)$ but this relationship is mainly driven by a few high points. The minimum adequate linear mixedeffects model showed significant effects of $\mathrm{N}$ deposition (parameter value $0.043, p<0.001$ ), altitude (parameter value $0.287, p<0.001$ ) and rainfall (parameter value $0.001, p<0.05$ ). 

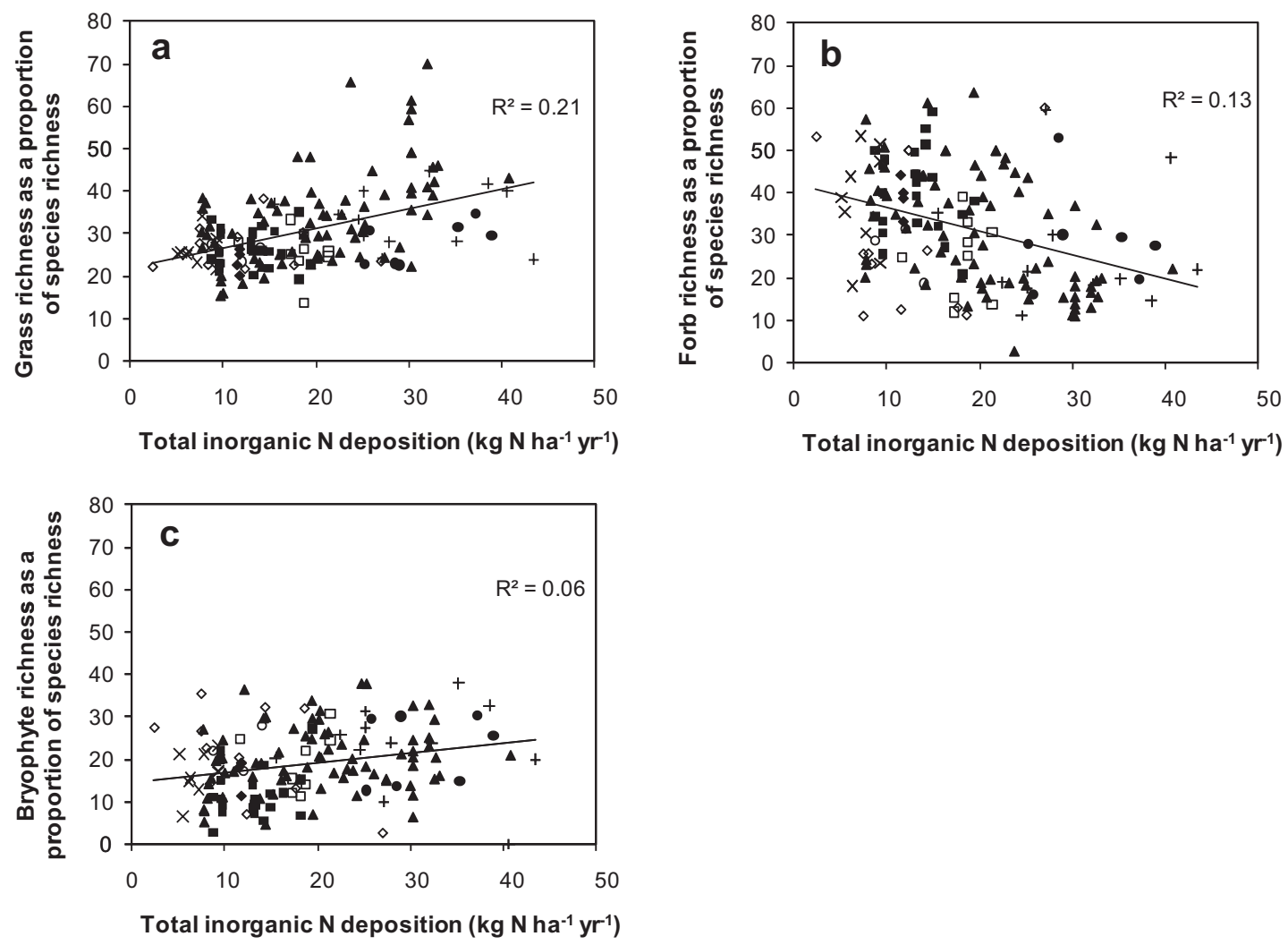

Fig. 2. Within functional group richness as a proportion of species richness for a) grasses, b) forbs and c) bryophytes against total inorganic $\mathrm{N}$ deposition for 153 acid grasslands in the Atlantic biogeographic regions of Europe. Symbols show the country from which data were collected: $\square$ Belgium, $\bigcirc$ Denmark, $\mathbf{\square}$ France, + Germany, $\diamond$ Ireland and Isle of Man,

- Netherlands, $\times$ Norway, $\bullet$ Sweden, and $\boldsymbol{\Delta}$ United Kingdom.

Total $\mathrm{N}$ content of the soil shows a weak but significant negative relationship with $\mathrm{N}$ deposition $\left(r^{2}=0.04, p<0.05\right)$ but, again, this relationship is mainly driven by high results from a few sites. This is confirmed by $\mathrm{N}$ deposition not being included in the minimum adequate linear mixed-effects model, significant effects were identified for longitude (parameter value $-0.023, p<0.001$ ), latitude (parameter value $0.035, p<0.001$ ) and altitude (parameter value $0.110, p<0.001$ ). There is no significant relationship between soil C content and $\mathrm{N}$ deposition $(p=0.06)$. The minimum adequate linear mixed-effects model showed significant effects of longitude (parameter value $-0.310, p<0.001$ ), latitude (parameter value 0.645 , $p<0.001$ ), altitude (parameter value 1.926, $p<0.001$ ) and vegetation height (parameter value $-0.155, p<0.05$ ). However, C: $\mathrm{N}$ ratio shows a significant positive relationship with $\mathrm{N}$ deposition $\left(r^{2}=0.15\right.$, $p<0.001$ ) (Fig. 3a). There is a clear significant negative relationship between C:N ratio and $\mathrm{pH}\left(r^{2}=0.29, p<0.001\right)$ (Fig. 3b).

\subsection{Plant-tissue chemistry}

A. capillaris was collected from a total of 148 sites. There is no significant relationship between $\mathrm{N}$ deposition and A. capillaris tissue $\mathrm{N}$ content ( $p=0.87$ ) (Fig. 4a), C:N ratio $(p=0.66)$ or $\mathrm{N}: \mathrm{P}$ ratio $(p=0.29)$. For tissue $\mathrm{N}$ content the minimum adequate linear mixed-effects model showed significant effects of latitude (parameter value -0.482 , $p<0.001$ ), soil $\mathrm{pH}$ (parameter value $-1.608, p<0.05$ ), $\mathrm{S}$ deposition (parameter value $0.172, p<0.05$ ), management intensity (parameter
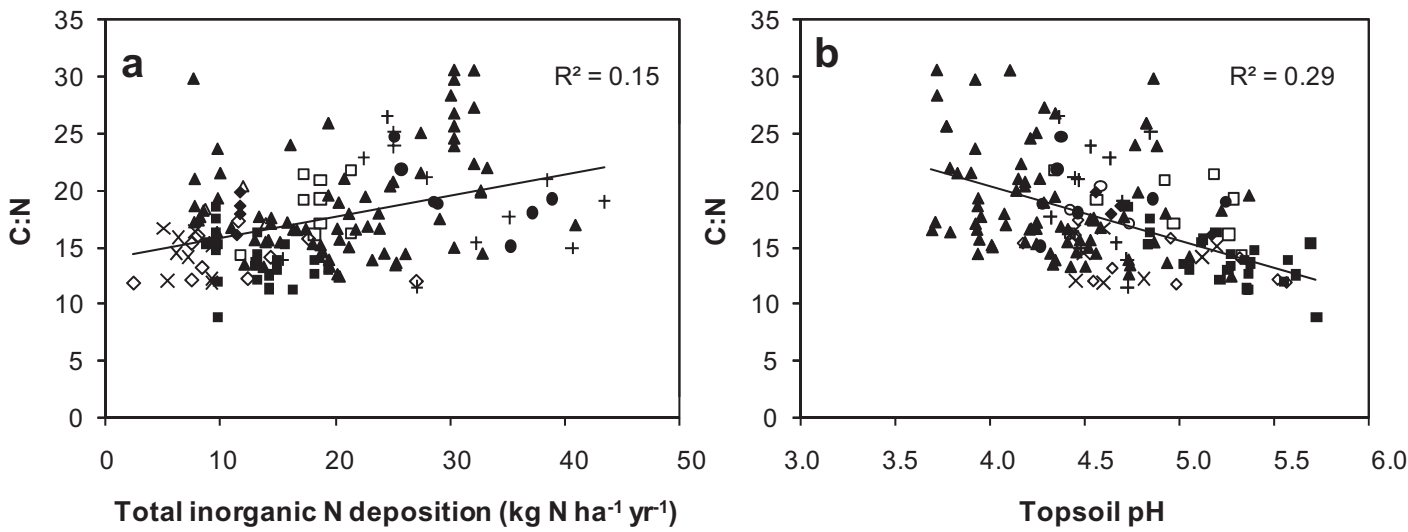

Fig. 3. Topsoil C:N ratio against a) total inorganic $\mathrm{N}$ deposition and b) pH for 153 acid grasslands in the Atlantic biogeographic regions of Europe. Symbols for countries are as in Fig. 2. 

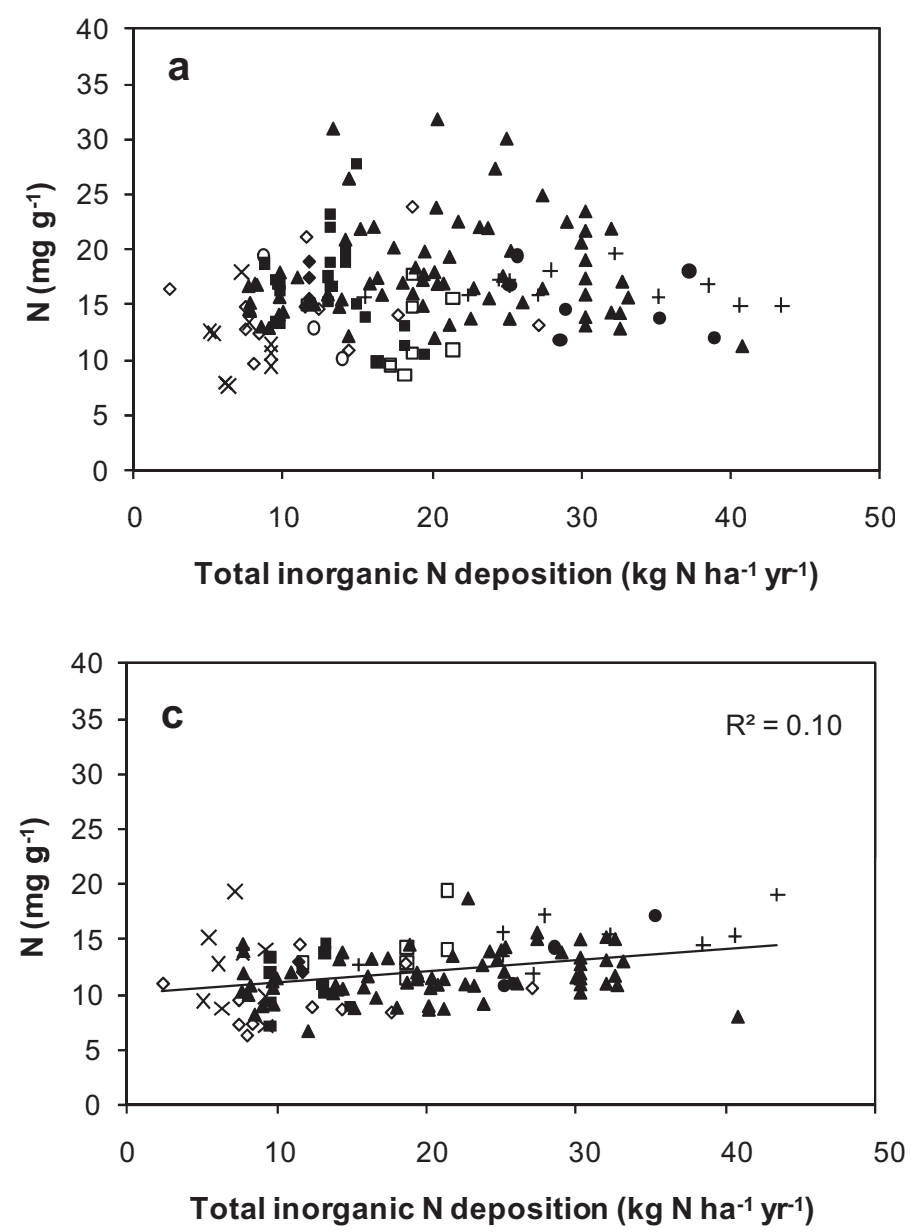

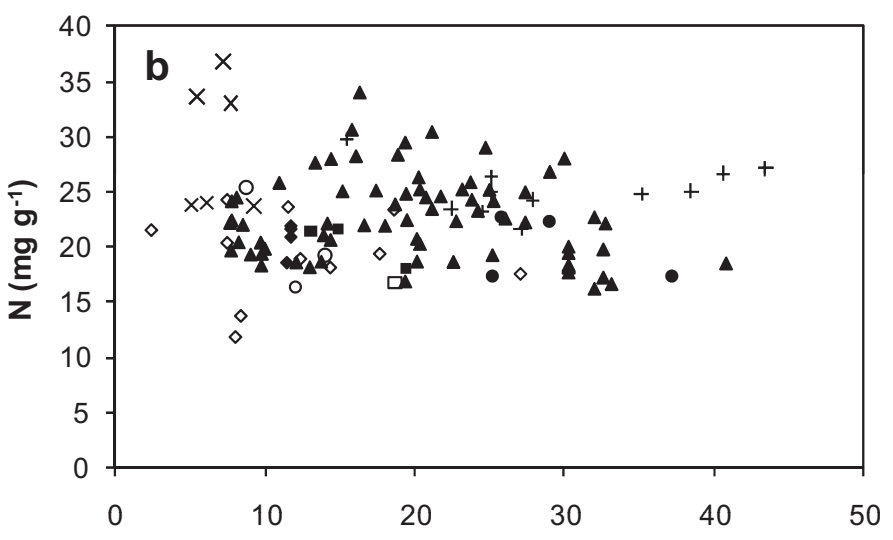

Total inorganic $\mathrm{N}$ deposition ( $\left.\mathrm{kg} \mathrm{N} \mathrm{ha}^{-1} \mathrm{yr}^{-1}\right)$

Fig. 4. Above-ground tissue $\mathrm{N}$ content for a) A. capillaris, b) G. saxatile and c) R. Squarrosus against total inorganic $\mathrm{N}$ deposition for 153 acid grasslands in the Atlantic biogeographic regions of Europe. Symbols for countries are as in Fig. 2.

value 1.159, $p<0.01$ ) and soil nitrate concentration (parameter value $0.413, p<0.01$ ). G. saxatile was collected from 115 sites, being most commonly absent from sites in France. There is no significant relationship between $\mathrm{N}$ deposition and $\mathrm{G}$. saxatile tissue $\mathrm{N}$ content $(p=0.42)$ (Fig. $4 \mathrm{~b})$ or $\mathrm{C}: \mathrm{N}$ ratio $(p=0.32) . \mathrm{N}: \mathrm{P}$ ratio has a weak but significant positive relationship with $\mathrm{N}$ deposition $\left(r^{2}=0.04, p<0.05\right)$. $R$. squarrosus was collected from a 148 sites. For tissue $\mathrm{N}$ content the minimum adequate linear mixed-effects model showed significant effects of soil carbon (parameter value $-0.167, p<0.001$ ), soil ammonium concentration (parameter value $0.726, p<0.001$ ) and soil nitrate concentration (parameter value 1.267, $p<0.001$ ). There is a weak but significant positive relationship between $\mathrm{N}$ deposition and R. squarrosus tissue $\mathrm{N}$ content $\left(r^{2}=0.10, p<0.001\right)$ (Fig. 4c). There is also a weak but significant negative relationship between $\mathrm{N}$ deposition and $R$. squarrosus C:N $\left(r^{2}=0.08, p<0.001\right)$ but not $\mathrm{N}: \mathrm{P}(p=0.20)$. For tissue $\mathrm{N}$ content the minimum adequate linear mixed-effects model showed significant effects of $\mathrm{N}$ deposition (parameter value 0.086 , $p<0.001$ ), longitude (parameter value 0.167, $p<0.001$ ), and management intensity (parameter value $0.584, p<0.05$ ).

\section{Discussion}

\subsection{Functional group composition}

There are clear relationships in the plant species composition data that show that the proportion of grass richness in the sward increases with increasing $\mathrm{N}$ deposition, whereas the proportion of forb richness decreases steeply. Species richness of forbs showed a significant reduction with increasing $\mathrm{N}$ deposition (Stevens et al., 2010a). A similar trend was observed in the earlier UK survey (Stevens et al., 2004) and other surveys (e.g. Stevens et al., 2009b; Duprè et al., 2010) as well as in N addition experiments (e.g. Mountford et al., 1993; Wilson et al., 1995). Although N deposition impacts are usually attributed primarily to eutrophication and the alteration of competitive interactions (e.g. Hautier et al., 2009), evidence from the UK now suggests that these grasslands may be responding primarily to acidification and its impacts on soil chemistry (Stevens et al., 2010b). In this acid grassland community competition for light may not be as important as in some other communities (e.g. prairie grasslands, Wedin and Tilman, 1993) in determining the response to $\mathrm{N}$ deposition. Although there is likely to be some effect of eutrophication, the continual removal of plant material through grazing and/or cutting may prevent competition for light and nutrients from being a strong determinant of community composition. An increase in the proportion of grasses in this community may simply reflect that many of the grasses found are very generalist species (e.g. Agrostis capillaris, Festuca ovina) or acid specialists (e.g. Deschampsia flexuosa, Molinia caerulea) that benefit from a reduction in forb cover. The strong relationship between forb richness and $\mathrm{N}$ deposition identified in the survey (Stevens et al., 2010a) indicates that this is the strongest driver of the changes in the proportional changes in richness.

The slight increase in bryophytes as a proportion of species number is a surprising trend, although this relationship is very 
weak and may be a consequence of the decline in forb richness. However, if the increase in bryophytes as a proportion of total species richness is a genuine trend, this would support the theory that competition for light is less important because in a short sward where competition for light was intense, we would expect an impoverished bryophyte flora (Peintinger and Bergamini, 2006) and that bryophytes would form a small proportion of total richness. Total species richness of bryophytes declines slightly with increasing $\mathrm{N}$ deposition but this is also not a strong trend (Stevens et al., 2010a).

For all of the functional groups, the proportion of richness shows weaker relationships with the oxidised and reduced components of $\mathrm{N}$ deposition considered when they are separately. However, in all cases the relationships between oxidised $\mathrm{N}$ deposition or reduced $\mathrm{N}$ deposition and the proportion of species richness are similar. This may be because they are correlated or because changes in species composition are slow reflecting chronic deposition over many years. The effects of recent changes in the ratio of reduced to oxidised $\mathrm{N}$ in deposition may not yet be apparent in the vegetation community. Although oxidised $\mathrm{N}$ and reduced $\mathrm{N}$ tend to have different sources (oxidised from burning fossil fuels and reduced from agricultural emissions) they are correlated within this data set. This makes it difficult to separate their effects through statistical means.

\subsection{Soil chemistry}

Stevens et al. (2004, 2006) reported a clear relationship between $\mathrm{N}$ deposition and soil $\mathrm{pH}$ and consequent mobilisation of metals within the soil (Stevens et al., 2009a) in the UK sites and, although the relationship is still apparent in this larger European data set, it is not as strong as in the UK alone $\left(r^{2}=0.39\right.$, Stevens et al., 2006, 2010a). The relationship between $\mathrm{N}$ deposition and soil $\mathrm{pH}$ found here supports evidence from other, smaller-scale surveys (e.g. Skiba et al., 1989) and long-term monitoring studies (e.g. Blake et al., 1999) that have demonstrated evidence for widespread soil acidification related to $\mathrm{N}$ deposition or acid deposition in weakly buffered soils.

It is possible that the wide range of soil types and underlying geology encompassed in the mainland European sites, together with a greater range in grassland-management techniques meant that trends in soil $\mathrm{pH}$ and aluminium concentration are not as clear in the large-scale European transect compared to the UK survey. Some of this variation is removed by looking at the $\mathrm{Al}$ :Ca ratio in the topsoil, but this only shows a weak relationship with $\mathrm{N}$ deposition. The availability of reactive aluminium in the soil is clearly related to $\mathrm{pH}$ despite variations in soil type. This is consistent with the known solubility of aluminium from experimental acidification of soils (Ulrich, 1991; Tyler and Olsson, 2001).

The slightly stronger relationship between soil $\mathrm{pH}$ or metal concentrations and total acid deposition (rather than $\mathrm{N}$ deposition alone) indicates that soil acidification in Europe is still related to either current or previous S deposition. However, because $\mathrm{N}$ and $\mathrm{S}$ deposition are somewhat correlated it is difficult to determine their relative contributions. This is also true when considering the relative contributions of the oxidised and reduced components of $\mathrm{N}$ deposition, in this case, relationships do appear to be stronger with oxidised deposition than with reduced. The relationship between $\mathrm{N}$ deposition and soil $\mathrm{pH}$ has implications for the species composition of the grasslands, which are reflected in the importance of soil pH as a driver of species richness (Stevens et al., 2010a). Reduction in $\mathrm{pH}$ and consequent mobilisation of metals could be changing the species composition from species typical of intermediate $\mathrm{pH}$ to acid-resistant species, especially considering that this habitat is already at the lower end of $\mathrm{pH}$ tolerance for most of the species typical of grasslands.

Given the variation in soil types and site conditions it is not surprising to see a lack of clear relationships between $\mathrm{N}$ deposition and soil nitrate and ammonium concentrations. In addition to soil variability, both nitrate and ammonium are readily utilised by plants and microbial communities, and nitrate is relatively mobile in the soil. Mixed-effects models showed that for both nitrate and ammonium concentration, climatic variables and altitude are important variables. Given that microbial processing of $\mathrm{N}$ is sensitive to climatic and seasonal variation and the direct impact these have on the amount of readily available $\mathrm{N}$, this relationship is not surprising (Morecroft et al., 1992). A significant positive relationship between $\mathrm{N}$ deposition and soil ammonium concentration was observed for the UK alone $\left(r^{2}=0.34\right.$; Stevens et al., 2006) adding further support to the hypothesis that increased variability in the soils, climate and site conditions in this larger study prevent trends being readily identified.

Although there is a relationship between total soil $\mathrm{N}$ and $\mathrm{N}$ deposition this is weak, and once one outlying point was removed the relationship was no longer significant. Given that leaching losses of $\mathrm{N}$ from these grasslands are likely to be quite low (Phoenix et al., 2003) it is possible that yet again soil variability, and particularly variation in soil organic matter content, is masking any changes in soil total $\mathrm{N}$. The soil $\mathrm{N}$ results from the European survey are in agreement with results from the UK alone $\left(r^{2}=0.08\right.$, Stevens et al., 2006) although the relationship is stronger in the European survey. Interestingly, C: $\mathrm{N}$ ratio increases with increasing $\mathrm{N}$ deposition (Fig. 3). This means that rather than $\mathrm{N}$ increasing relative to the amount of $\mathrm{C}$ as might be expected through the addition of $\mathrm{N}, \mathrm{C}$ is actually increasing relative to $\mathrm{N}$. Increased soil $\mathrm{C}$ in response to $\mathrm{N}$ deposition has been reported in several studies in different habitats (e.g. Knorr et al., 2005; de Vries et al., 2009). Increases in soil C relative to soil $\mathrm{N}$ are possibly related to increased productivity leading to increased litter and/or changes in the decomposition rate of litter. Measurement of standing biomass, soil organic matter dynamics and litter decomposition would confirm whether this is the case in the acid grassland system investigated in this study. All of the grasslands in this survey were managed for agriculture either by cutting or grazing. This continual removal of plant material make it less likely that changes in productivity will impact the ecosystem. Another possible explanation is reduced soil respiration leading to $C$ accumulation in the soil as has been observed in forest ecosystems (e.g. Mo et al., 2007; Bowden et al., 2004; Burton et al., 2004). The clear relationship with soil $\mathrm{pH}$ suggests that the effect is related to acidification impacting on soil processes.

\subsection{Plant-tissue chemistry}

Many experimental studies have demonstrated relationships between $\mathrm{N}$ addition and plant-tissue $\mathrm{N}$ content (e.g. Carroll et al., 2003; Gordon et al., 2001; Leith et al., 1999,) but these are not reflected in this gradient study. It is possible that short-term $\mathrm{N}$ additions in experimental applications are not fully representative of chronic $\mathrm{N}$ deposition leading to a different response from plants or background variation in $\mathrm{N}$ availability may be masking this trend across natural gradients. It is clear from the plant-tissue chemistry results that responses are species-specific which may also account for some of the different results observed. For A. capillaris there were no significant relationships between $\mathrm{N}$ deposition and any of the tissuenutrient content measurements ( $\mathrm{N}, \mathrm{C}: \mathrm{N}$ and $\mathrm{N}: \mathrm{P})$. $R$. squarrosus showed slightly different results, with a significant relationships observed between tissue $\mathrm{N}$ content and C: $\mathrm{N}$ ratio with $\mathrm{N}$ deposition, but not for N:P ratio. In the UK alone the relationship between $\mathrm{N}$ deposition and tissue $\mathrm{N}$ was not observed (Stevens et al., 2006). 
Results are generally in good agreement with Stevens et al. (2006). $R$. squarrosus showed slightly different results, with a significant relationships observed between tissue $\mathrm{N}$ content and C: $\mathrm{N}$ ratio with $\mathrm{N}$ deposition but this relationship is very weak and is unlikely to be ecologically relevant. In the UK alone the relationship between $\mathrm{N}$ deposition and tissue $\mathrm{N}$ was not observed (Stevens et al., 2006). This suggests that although this was the strongest of the relationships between tissue chemistry and $\mathrm{N}$ deposition recorded in this study, it is not necessarily suitable for application as an indicator of $\mathrm{N}$ deposition at a national scale. This conclusion is supported by an intensive investigation of experimental $\mathrm{N}$ additions to a similar grassland community who also found no relationship between $\mathrm{N}$ deposition and $R$. squarrosus tissue $\mathrm{N}$ content (Arroniz-Crespo et al., 2008).

There are a number of potential reasons that strong relationships between tissue-nutrient concentrations and $\mathrm{N}$ deposition are not observed in this study. In this gradient study, there are many different variables with the potential to affect tissue $\mathrm{N}$ content, including climatic and management variations. The mixed-effects models show that some of these variables are significantly related to tissue $\mathrm{N}$ content. In a controlled experimental situation these may be less apparent. The lack of relationship between $\mathrm{N}$ deposition and plant-nutrient concentrations may also relate to the microbial processing of $\mathrm{N}$ in the soil resulting in different amounts and forms of $\mathrm{N}$ being available to plants compared to that which is deposited. The microbial processing of $\mathrm{N}$ varies on a small spatial and temporal scale and is affected by a range of factors including temperature, soil moisture, soil $\mathrm{pH}$ and soil carbon content as well as $\mathrm{N}$ input (e.g. Riaz et al., 2008). Furthermore, the plants investigated in this study may be using the additional $\mathrm{N}$ deposited from the atmosphere for increased growth, as supported by optimal partitioning theory, which suggests that plants equalize nutrient exchange ratios in order to maximize the efficiency of resource use (Bloom et al., 1985). The collection of productivity data would confirm whether this is the case. An alternative possibility is that these plants may be showing a very plastic response to $\mathrm{N}$ deposition, with tissue nutrients changing in response to very short-term changes in $\mathrm{N}$ deposition levels (Dise and Gundersen, 2004). If this is the case, small-scale spatial and temporal variations in deposition, which are not accounted for in using a larger scale modelled $\mathrm{N}$ deposition data, may have a role to play in the variability of the results observed. Seasonal variation in resource allocation may also play a role in the lack of relationships between tissue-nutrient concentrations and $\mathrm{N}$ deposition. Relationships between tissue $\mathrm{N}$ content and $\mathrm{N}$ deposition may not be apparent in above-ground tissues year-round and there may be seasonal variability in tissue $\mathrm{N}$ concentration which has not been eliminated in this study. An alternative indicator to tissue-nutrient concentrations may be the use of metabolic fingerprints or enzymes such as phosphomonoesterase which have generated some interesting results from initial studies (Arroniz-Crespo et al., 2008; Gidman et al., 2006; Hogan et al., 2010).

\section{Conclusion}

Species composition of acid grasslands in Europe shows clear relationships with $\mathrm{N}$ deposition. The proportion of species richness that is made up of forb species is negatively associated with $\mathrm{N}$ deposition whilst the proportion of grasses increases.

Soil chemistry results show no relationships between $\mathrm{N}$ deposition and soil $\mathrm{N}$ (extractable nitrate, ammonium and total $\mathrm{N}$ ), but relationships between $\mathrm{N}$ deposition and soil $\mathrm{pH}$ and $\mathrm{Al}$ concentration can be observed. Soil C:N shows a positive relationship with $\mathrm{N}$ deposition. This result has important implications for carbon storage but further research is needed to determine the mechanism causing this increase.
The results of this survey demonstrate that tissue $\mathrm{N}$ concentrations of the three species investigated are not suitable for use as indicators of $\mathrm{N}$ deposition. Some species may be more suitable, but before they are recommended for use as an indicator of $\mathrm{N}$ deposition, their response to chronic $\mathrm{N}$ deposition should be investigated outside of controlled experimental situations.

These results clearly show a correlation between atmospheric $\mathrm{N}$ deposition and species composition and soil chemistry of European grasslands at ambient levels of $\mathrm{N}$ deposition suggesting that deposition levels need to be reduced to protect these grasslands. The results show that changes occur at all levels of deposition found within the region including impacts on vegetation community and soil below the critical load for $\mathrm{N}$ deposition for this habitat. This would suggest that achieving no damage to sensitive acid grasslands from $\mathrm{N}$ deposition is not a realistic goal and policy makers should instead aim to minimise impacts on acid grasslands. The results also show that even at high deposition impacts continue to occur suggesting that further $\mathrm{N}$ additions to areas where the critical load is currently exceeded could cause further damage.

\section{Acknowledgements}

This project was funded by the European Science Foundation through the EURODIVERSITY-programme, and national funds were provided by DfG (Germany), NERC (United Kingdom), NWO (The Netherlands) and INRA, ADEME and Aquitaine Region (France). We are grateful to everyone who assisted with field and laboratory work, and conservation agencies and land owners who gave permission for sampling.

\section{References}

Aerts, R., Chapin, F.S., 2000. The mineral nutrition of wild plants revisited: a reevaluation of processes and patterns. Advances in Ecological Research 30,1-67.

Arroniz-Crespo, M., Leake, J.R., Horton, P., Phoenix, G.K., 2008. Bryophyte physiological responses to, and recovery from, long-term nitrogen deposition and phosphorus fertilisation in acidic grassland. New Phytologist 180, 864-874.

Asman, W.A.H., van Jaarsveld, J.A., 2002. A variable-resolution transport model applied for $\mathrm{NH}_{\mathrm{x}}$ in Europe. Atmospheric Environment 26A, 445-464.

Berger, T.W., Inselsbacher, E., Mutsch, F., Pfeffer, M., 2009. Nutrient cycling and soil leaching in eighteen pure and mixed stands of beech (Fagus sylvatica) and spruce (Picea abies). Forest Ecology and Management 258, 2578-2592.

Blake, L., Goulding, K.W.T., Mott, C.J.B., Johnston, A.E., 1999. Changes in soil chemistry accompanying acidification over more than 100 years under woodland and grass at Rothamsted Experimental Station, UK. European Journal of Soil Science 50, 401-412.

Bloom, A.J., Chapin, F.S., Mooney, H.A., 1985. Resource limitation in plants - an economic analogy. Annual Review of Ecology and Systematics 16, 363-392.

Bobbink, R., Hicks, K., Galloway, J., Spranger, T., Alkemade, R., Ashmore, M., Bustamante, M., Cinderby, S., Davidson, E., Dentener, F., Emmett, B., Erisman, J.W., Fenn, M., Gilliam, F., Nordin, A., Pardo, L., De Vries, W., 2010. Global assessment of nitrogen deposition effects on terrestrial plant diversity: a synthesis. Ecological Applications 20, 30-59.

Bobbink, R., Hornung, M., Roelofs, J.G.M., 1998. The effects of air-borne nitrogen pollutants on species diversity in natural and semi-natural European vegetation. Journal of Ecology 86, 717-738.

Bowden, R.D., Davidson, E., Savage, K., Arabia, C., Steudler, P., 2004. Chronic nitrogen additions reduce total soil respiration and microbial respiration in temperate forest soils at the Harvard Forest. Forest Ecology and Management 196, 43-56.

Brunsting, A.M.H., Heil, G.W., 1985. The role of nutrients in the interactions between a herbivorous beetle and some competing plant species in heathlands. Oikos $44,23-26$.

Burton, A.J., Pregitzer, K.S., Crawford, J.N., Zogg, G.P., Zak, D.R., 2004. Simulated chronic $\mathrm{NO}_{3}$ - deposition reduces soil respiration in northern hardwood forests. Global Change Biology 10, 1080-1091.

Carroll, J.A., Caporn, S.J.M., Cawley, L., Read, D.J., Lee, J.A., 1999. The effect of increased atmospheric nitrogen on Calluna vulgaris in upland Britain. New Phytologist 141, 423-431.

Carroll, J.A., Caporn, S.J.M., Johnson, D., Morecroft, M.D., Lee, J.A., 2003. The interactions between plant growth, vegetation structure and soil processes in seminatural acidic and calcareous grasslands receiving long-term inputs of simulated pollutant nitrogen deposition. Environmental Pollution 121, 363-376.

Chapman, H.D., Pratt, P.F., 1985. Methods for Analysis of Soils, Plants and Waters. Agricultural Sciences Publications, California. 
Clark, C.M., Cleland, E.E., Collins, S.L., Fargione, J.E., Gough, L., Gross, K.L., Pennings, S.C., Suding, K.N., Grace, J.B., 2007. Environmental and plant community determinants of species loss following nitrogen enrichment Ecology Letters 10, 596-607.

Duprè, C., Stevens, C.J., Ranke, T., Bleeker, A., Peppler-Lisbach, C., Gowing, D.J.G., Dise, N.B., Dorland, E., Bobbink, R., Diekmann, M., 2010. Changes in specie richness and composition in European acidic grasslands over the past 70 years the contribution of cumulative atmospheric nitrogen deposition. Global Change Biology 16, 344-357.

de Vries, W., Solberg, S., Dobbertin, M., Sterba, H., Laubhann, D., van Oijen, M., Evans, C., Gundersen, P., Kros, J., Wamelink, G.W.W., Reinds, G.J., Sutton, M.A. 2009. The impact of nitrogen deposition on carbon sequestration by European forests and heathlands. Forest Ecology and Management 258, 1814-1823.

Dise, N.B., Gundersen, P., 2004. Forest ecosystem responses to atmospheric pollution: linking the empirical with the experimental. Water, Air and Soil Pollution: Focus 4, 207-220.

Erisman, J.W., Bleeker, A., Hensen, A., Vermeulen, A., 2008. Agricultural air quality in Europe and the future perspectives. Atmospheric Environment 42, 3209-3217.

Fagerli, H., Aas, W., 2008. Trends of nitrogen in air and precipitation: model results and observations at EMEP sites in Europe, 1980-2003. Environmental Pollution $154,448-461$.

Falkengren-Grerup, U., 1995. Long-term changes in flora and vegetation in deciduous forests of southern Sweden. Ecological Bulletins 44, 215-226.

Galloway, J.N., Townsend, A.R., Erisman, J.W., Bekunda, M., Cai, Z., Freney, J.R., Martinelli, L.A., Seitzinger, S.P., Sutton, M.A., 2008. Transformation of the nitrogen cycle: recent trends, questions and potential solutions. Science 320 , 889-892.

Gauger, T., Anshelm, F., Schuster, H., Erisman, J.W., Vermeulen, A.T., Draaijers, G.P.J., Bleeker, A., Nagel, H.-D., 2002. Mapping of Ecosystems Specific Long-term Trends in Deposition Loads and Concentrations of Air Pollutants in Germany and Their Comparison with Critical Loads and Critical Levels. Institut fur Navigation, University of Stuttgart, Germany.

Gidman, E.A., Stevens, C.J., Goodacre, R., Broadhurst, D., Emmett, B., Gwynn-Jones, D. 2006. Loss of forb diversity in relation to nitrogen deposition in the UK: regional trends and potential controls. Global Change Biology 12, 1823-1833.

Gordon, C., Wynn, J.M., Woodin, S.J., 2001. Impacts of increased nitrogen supply on high Arctic heath: the importance of bryophytes and phosphorus availability. New Phytologist 149, 461-471.

Hautier, Y., Niklaus, P.A., Hector, A., 2009. Competition for light causes plant biodiversity loss after eutrophication. Science 324, 636-638.

Hogan, E.J., Minnullina, G., Smith, R.I., Crittenden, P.D., 2010. Effects of nitrogen enrichment on phosphatase activity and N/P relationships in Cladonia portentosa. New Phytologist 186, 911-925.

Johnston, A.E., Goulding, K.W.T., Poulton, P.R., 1986. Soil acidification during more than 100 years under permanent grassland and woodland at Rothamstead. Soil Use and Management 2, 3-10.

Knorr, M., Frey, S.D., Curtis, P.S., 2005. Nitrogen additions and litter decomposition: a meta-analysis. Ecology 86, 3252-3257.

Leith, I.D., Hicks, W.K., Fowler, D., Woodin, S.J., 1999. Differential responses of UK upland plants to nitrogen deposition. New Phytologist 141, 277-289.

Mace, G., Masundire, H., Baille, J. (Eds.), 2005. Millenium Ecosystem Assessment. Current States and Trends, vol. 1. Island Press, Washington.

MAFF, 1986. The Analysis of Agricultural Materials, third ed. Her Majesty's Stationary Office, London.

Maskell, L.C., Smart, S.M., Bullock, J.M., Thompson, K., Stevens, C.J., 2010. Nitrogen deposition causes widespread species loss in British habitats. Global Change Biology 16, 671-679.

Mo, J.M., Brown, S., Xue, J.H., Fang, Y.T., Li, Z., Li, D.J., Dong, S.F., 2007. Response of nutrient dynamics of decomposing pine (Pinus massoniana) needles to simulated $\mathrm{N}$ deposition in a disturbed and a rehabilitated forest in tropical China. Ecological Research 22, 649-658.

Monitoring Agricultural Resources(MARS), European Commission Joint Research Centre http://mars.jrc.it/mars/About-us/The-MARS-Unit (accessed November 2009).

Morecroft, M.D., Marrs, R.H., Woodward, F.I., 1992. Altitudinal and seasonal trends in soil mineralization rate in the Scottish Highlands. Journal of Ecology 80, 49-56.

Mountford, J.O., Lakhani, K.H., Kirkham, F.W., 1993. Experimental assessment of the effects of nitrogen addition under hay-cutting and aftermath grazing on the vegetation of meadows on a Somerset peat moor. Journal of Applied Ecology 30 321-332.

NEGTAP, 2001. Transboundary Air Pollution: Acidification, Eutrophication and Ground-level Ozone in the UK. CEH, Edinburgh

Oke, T.R., 1987. Boundary Layer Climates, second ed.. Methuen, New York

Pearson, J., Stewart, G.R., 1993. Tansley Review No.56. The deposition of atmospheric ammonia and its effects on plants. New Phytologist 125, 283-305.
Peintinger, M., Bergamini, A., 2006. Community structure and diversity of bryophytes and vascular plants in abandoned fen meadows. Plant Ecology 185, 1-17.

Phoenix, G.K. Booth, R.E, Leake, J.R. Read, D.J, Grime, P., Lee, J.A., 2003. Effects of enhanced nitrogen deposition and phosphorus limitation on nitrogen budgets of semi-natural grasslands. Global Change Biology 9, 1309-1321.

Pieterse, G., Bleeker, A., Vermeulen, A.T., Wu, Y., Erisman, J.W., 2007. High resolution modelling of atmosphere-canopy exchange of acidifying and eutrophying components and carbon dioxide for European forests. Tellus 59B, 412-424.

Pilkington, M.G., Caporn, S.J.M., Carroll, J.A., Cresswell, N., Lee, J.A., Emmett, B.A., Johnson, D., 2005. Effects of increased deposition of atmospheric nitrogen on an upland Calluna moor: N and P transformation. Environmental Pollution 135, 469-480.

Pitcairn, C.E.R., Leith, I.D., Sheppard, L.J., Sutton, M.A., Fowler, D., Munro, R.C. Tang, S., Wilson, D., 1998. The relationship between nitrogen deposition, species composition and foliar nitrogen concentrations in woodland flora in the vicinity of livestock farms. Environmental Pollution 102, 41-48.

R Development Core Team, 2007. R: a Language and Environment for Statistical Computing. R Foundation for Statistical Computing, Vienna, Austria.

Riaz, M., Mian, I.A., Cresser, M.S., 2008. Extent and causes of 3D spatial variations in potential $\mathrm{N}$ mineralization and the risk of ammonium and nitrate leaching from an N-impacted permanent grassland near York, UK. Environmental Pollution 156, 1075-1082.

Ryan, J., Estefan, G., Rashid, A., 2001. Soil and Plant Analysis Laboratory Manual, second ed. ICARDA, Aleppo, Syria.

Sala, O.E., Chapin, F.S., Armesto, J.J., Berlow, E., Bloomfield, J., Dirzo, R., HuberSanwald, E., Huenneke, L.F., Jackson, R.B., Kinzig, A., Leemans, R., Lodge, D.M. Mooney, H.A., Oesterheld, M., Poff, N.L., Sykes, M.T., Walker, B.H., Walker, M., Wall, D.H., 2000. Biodiversity - global biodiversity scenarios for the year 2100 Science 287, 1770-1774.

Schwickerath, M., 1944. Das Hohe Venn und seine Randgebiete. Pflanzensoziologie $6,1-278$.

Sheppard, L.J., Leith, I.D., 2002. Effects of $\mathrm{NH}_{3}$ fumigation on the frost hardiness of Calluna - does $\mathrm{N}$ deposition increase winter damage by frost? Phyton-annales Rei Botanicae 42, 183-190.

Skiba, U., Cresser, M.S., Derwent, R.G., Futty, D.W., 1989. Peat acidification in Scotland. Nature 337, 68-70.

Smith, R.I., Fowler, D., Sutton, M.A., Flechard, C., Coyle, M., 2000. Regional estimation of pollutant gas dry deposition in the UK: model description, sensitivity analyses and outputs. Atmospheric Environment 34, 3757-3777.

Stevens, C.J., Dise, N.B., Mountford, J.O., Gowing, D.J., 2004. Impact of nitrogen deposition on the species richness of grasslands. Science 303, 1876-1879.

Stevens, C.J., Dise, N.B., Gowing, D.J., Mountford, J.O., 2006. Loss of forb diversity in relation to nitrogen deposition in the UK: regional trends and potential controls. Global Change Biology 12, 1823-1833.

Stevens, C.J., Dise, N.B., Gowing, D.J., 2009a. Regional trends in soil acidification and metal mobilisation related to acid deposition. Environmental Pollution 157, 313-319.

Stevens, C.J., Maskell, L.C., Smart, S.M., Caporn, S.J.M., Dise, N.B., Gowing, D.J., 2009b. Identifying indicators of atmospheric nitrogen deposition impacts in acid grasslands. Biological Conservation 142, 2069-2075.

Stevens, C.J., Duprè, C., Dorland, E., Gaudnik, C., Gowing, D.J.G., Bleeker, A., Diekmann, M., Alard, D., Bobbink, R., Fowler, D., Corcket, E., Mountford, J.O. Vandvik, V., Aarrestad, P.A., Muller, S., Dise, N.B., 2010a. Nitrogen deposition threatens species richness of grasslands across Europe. Environmental Pollution $158,2940-2945$.

Stevens, C.J., Thompson, K., Grime, J.P., Long, C.J., Gowing, D.J.G., 2010b. Contribution of acidification and eutrophication to declines in species richness of calcifuge grasslands along a gradient of atmospheric nitrogen deposition. Functional Ecology 24, 478-484.

Throop, H.L., Lerdau, M.T., 2004. Effects of nitrogen deposition on insect herbivory: implications for community and ecosystem processes. Ecosystems 7, 109-133.

Tyler, G., Olsson, T., 2001. Concentrations of 60 elements in the soil solution as related to soil acidity. European Journal of Soil Science 52, 151-165.

Ulrich, B., 1991. An ecosystem approach to soil acidification. In: Ulrich, B. Sumner, M.E. (Eds.), Soil Acidity. Springer-Verlag, Berlin, pp. 28-79.

Van Jaarsveld, J.A., 1995. Modelling the Long-term Atmospheric Behaviour of Pollutants on Various Spatial Scales. University of Utrecht, The Netherlands.

Van Jaarsveld, J.A., 2004. The Operation Priority Substances Model. National Institute for Public Health and the Environment (RIVM), Bilthoven, The Netherlands.

Wedin, D., Tilman, D., 1993. Competition among grasses along a nitrogen gradient: initial conditions and mechanisms of competition. Ecological Monographs 63 199-229.

Wilson, E.J., Wells, T.C.E., Sparks, T.H., 1995. Are calcareous grasslands in the UK under threat from nitrogen deposition? - an experimental determination of a critical load. Journal of Ecology 83, 823-832. 